\title{
Temporal change detection of Kahphuche glacial lake Kaski District, Nepal
}

\author{
"Saroj Koirala', Judy Oglethorpe', Kapil Khanal', Suman Dhakal', Khagendra Raj Poudel', Kalidas Sharma², \\ and Krishna Bhandari ${ }^{3}$ \\ ${ }^{1}$ World Wildlife Fund Nepal, Kathmandu \\ ${ }^{2}$ Prithvi Narayan Campus, Pokhara \\ ${ }^{3}$ Institute of Engineering, Paschimanchal Campus, Pokhara \\ *(Corresponding email: saroj.koirala@wwfnepal.org)
}

\begin{abstract}
This study analyzes the temporal trend of the Kahphuche glacier lake from 1990 to 2016 using multi-temporal satellite imagery to explore the glaciological causes of lake expansion. The Kahphuche glacial lake, has increased perceptibly in size over the last one and half decades, and it continues to expand. This study reveals that the glacial lake is not likely to burst in the near future as it is dammed by a $348 \mathrm{~m}$ wide moraine dam. However, the probability of a GLOF may occur if there is an avalanche or rock-fall, or seismic disturbance.
\end{abstract}

Keywords: Climate change, glacier hazards, remote sensing, GIS

Received: 27 December 2016

Revision accepted: 5 June 2017

\section{INTRODUCTION}

The Himalayan mountain range is about $2,400 \mathrm{~km}$ in length and is one of the most tectonically active mountain ranges in the world. The mountainous terrain of the Himalayas is home to millions of people living in Nepal, India, Pakistan, Afghanistan, Bhutan, China and parts of other Asian nations. The rugged topography, unstable geological structures, soft and fragile rocks, earthquakes, and heavy and concentrated rainfall during monsoon season cause severe landslides and related phenomena in the Himalayan region (Dahal and Hasegawa 2008). The great seasonality in rainfall results in natural hazards, especially the water induced disasters. Landslides in the Himalaya are scale-dependent, from the massive extent of whole mountain ranges (gravity tectonics) to failure of single peaks to very minor slope failures (Shroder and Bishop 1998).

The Nepal Himalaya includes 3,808 glaciers covering 4,212 sq. $\mathrm{km}$, and 2,323 glacial lakes are located above 4,000 m (ICIMOD 2010). As global warming causes glaciers to melt more rapidly, the surface area and water volume in the glacial lakes are expanding in the Himalaya. This can pose serious threats to people and ecosystems in the high mountains and downstream. Glacial lakes are created by water flows from glacier and snow melt naturally dammed by moraines. The process of rapid snow and glacial melting initially increases runoff in some regions. The moraines can withstand a certain amount of water pressure, and when the pressure is too great, the moraine wall can break and discharge a huge volume of water and debris, causing flooding. The lack of a glacial buffer ultimately reduces the reliability of dry season stream flow, which affects agriculture, ecosystems, hydropower, and water supply. These changes are superimposed on other drivers in local society, creating profound impacts on mountain communities and downstream populations (ICIMOD 2010).

In South Asia, particularly in the Himalayan region, the frequency of the occurrence of Glacial Lake Outburst Flood (GLOF) events has increased in the second half of the 20th century (Bajracharya et al. 2002). The glaciers, some of which consist of a huge amount of perpetual snow and ice, create many glacial lakes. These glaciers and glacial lakes are the sources of the headwaters of many rivers in the region. Most of these lakes are located in valleys close to the glaciers. A close monitoring of such glacial lakes is important to prevent the loss and damage they bring when the outburst flood occurs. One of the less studied and potential to of outburst flood is Kahphuche glacial lake. This study analyzes the temporal change of Kahphuche lake in reference to the time series imageries and observations (Shrestha and Balla 2011).

\section{STUDY AREA}

The Kahphuche Lake is located at the source of the Madi River. The lake is situated about $12 \mathrm{~km}$, and eight hours uphill walk, from Sikles village. The lake is located at $28^{\circ} 26^{\prime} 28^{\prime \prime}$ North latitude and $84^{\circ} 07^{\prime} 00^{\prime \prime}$ East longitude at an elevation of 2,435 m in upper Madi, Parche VDC, Kaski District (Fig. 1). The glacial lake is formed after ice sheets melted in the area, with the meltwater filling the space at a lower elevation. The local people have known about the existence of the lake for several years, but it was publicly recognized only recently. 


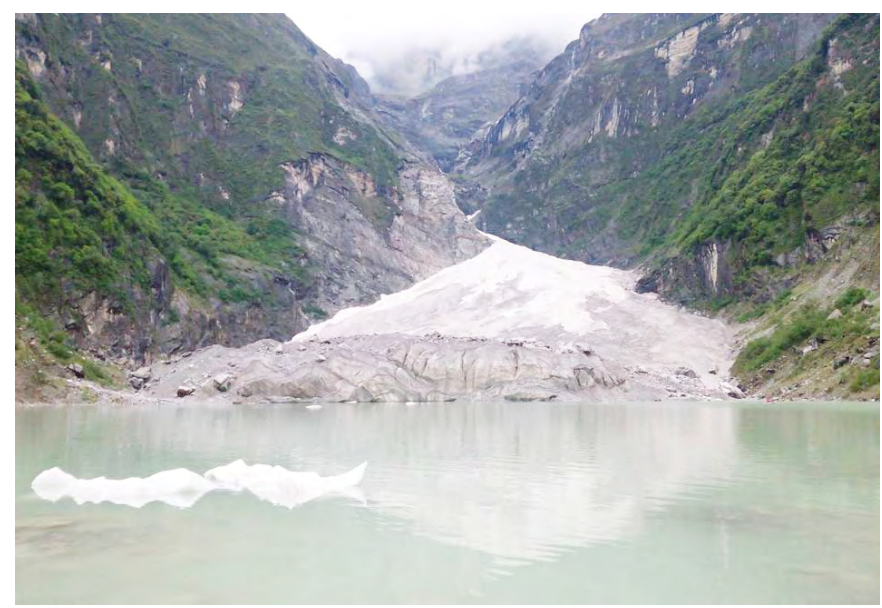

Fig. 1: Kahphuche (Gopche) Glacial Lake

\section{METHODOLOGY}

\section{Data collection}

Main data source was obtained from three different sources: (i) maps, aerial photographs and satellite imagery; (ii) field survey and group discussions; and iii) published and unpublished documents. Landsat Thematic Mapper images and Landsat Enhanced Thematic Mapper Plus (ETM+) satellite images were acquired and analysed to identify and map critical features of the landscape. Different time series images of Landsat from 1990, 2000, 2005, 2010 and 2016 were used for the temporal change analysis. Field observations were carried out for better understanding physical condition of surrounding, geological structure, rock types, scenario of present lake, moraine condition and outlet of Kahphuche glacial lake (Fig. 2). Sufficient ground truthing were conducted by collecting number of Global Positioning System (GPS) points.

\section{Data analysis}

Multispectral series of Landsat satellite imageries and topographic maps were used and analysed by Erdas Imagine 2011, QGIS 2.12.1, Arc GIS 10.4 and eCognition 8.7 software. Radiometric and Geometric correction of satellite imageries carried out by using topographic map and Google Earth Pro. For digital spatial data layers, Digital Elevation Models (DEM) were used to generate terrain parameters such as elevation, slope, and length as measuring units for glacial lakes. Time series satellite images were used to analyze the changes in glacial lake size.

\section{RESULTS AND DISCUSSION}

\section{Glacier Condition}

The outer slope of the moraine dam is covered with vegetation, while the inner slope is bare and unstable, a characteristic common to moraine dams in contact with a lake. The moraine dam expands about $348 \mathrm{~m}$ wide from the south-east bank of the lake. The natural outlet is at an elevation of 2,435 meters to 2,429 meters, and the lowest point in the terminal moraine is covered by vegetation with the flow of Madi River on the surface. The Landsat imagery between 1990 and 2016 indicates that the Kahphuche glacial lake is increasing rapidly.

\section{Moraine Dam Condition}

In this glacial lake, meltwater is trapped between the glacier terminus and the end moraine. The lake seems to be formed by accumulation along the glacier margins, between the lateral moraine and the side of the valley. Depending on the topography of the end moraine, small lakes seem to form because of water accumulation in the numerous depressions that are characteristic of the terrain. The steep slope of Annapurna II (7,937 m), at about a 70 degree angle and height of 5,502 $\mathrm{m}$ from the lake, is the main geographical element responsible for the formation of the glacial lake. Avalanches, rock falls and huge icebergs separating also contribute to the formation of this glacial lake at a low elevation.

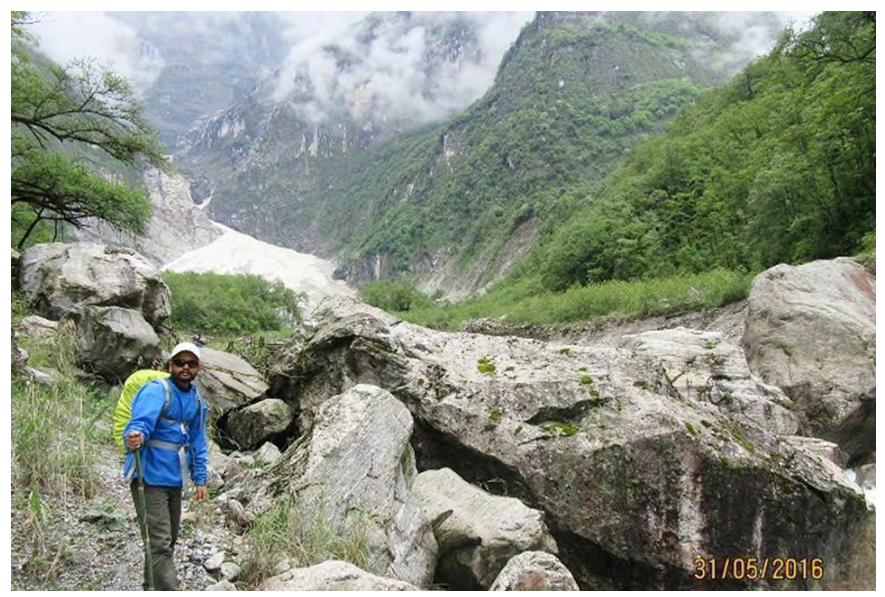

Fig. 2: Dam of Kahphuche Lake.

\section{Development of Glacial Lake (Temporal Changes)}

The development history of the lake has been attempted by gathering information from local publications and anecdotal statements from local people. According to these accounts, small holes were seen between ice sheets in the summer season and day time before 1990. This, however, was not recorded in any documents. The topographic map produced in this study traced narrow plain topography with water without a lake name in 1998. Landsat imagery captured in 2000 demonstrates that, except for several small melt ponds on the glacier surface, the lake did not exist. By 2005, a lake approximately $16,784.84 \mathrm{~m}^{2}$ had been formed. Since that time, the Kahphuche glacial lake has been in existence (Fig. 3). The area of Kahphuche glacial lake in different years was determined using the available satellite imagery from 2000, 2005, 2010 and 2016. The results showed a remarkable increase in the glacial lake over the period of 15 years (2000-2016). The area of the lake increased in a ten-year period from $10,455.52 \mathrm{~m}^{2}$ to $104,040.69 \mathrm{~m}^{2}$. This increment is likely due to the melting of glacier ice and inflow from the small stream into the lake from the upstream endglacier channel (Table 1) 

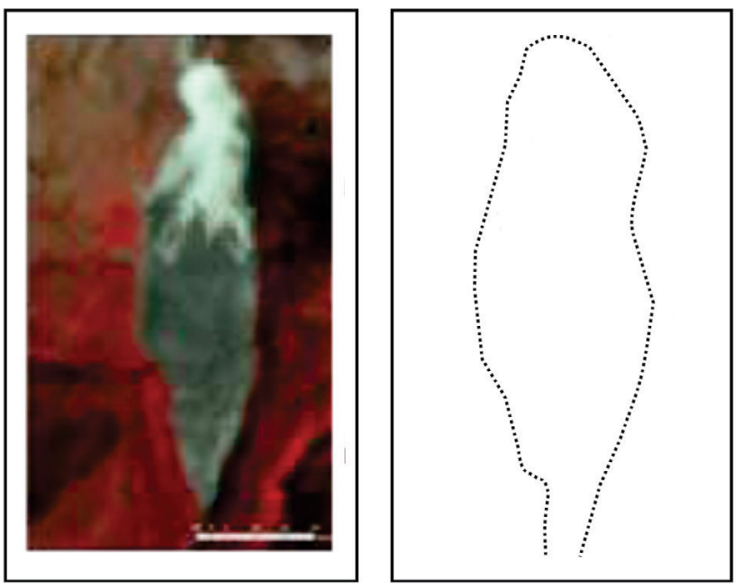

1990 January: Landsat image, there is no any sign of Lake
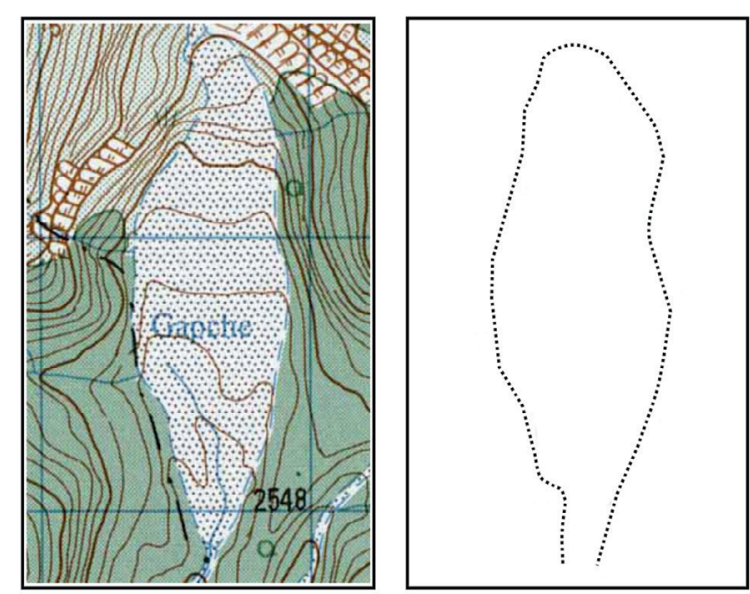

1996: Topographic map (based on aerial photograph) Department of Survey, Nepal
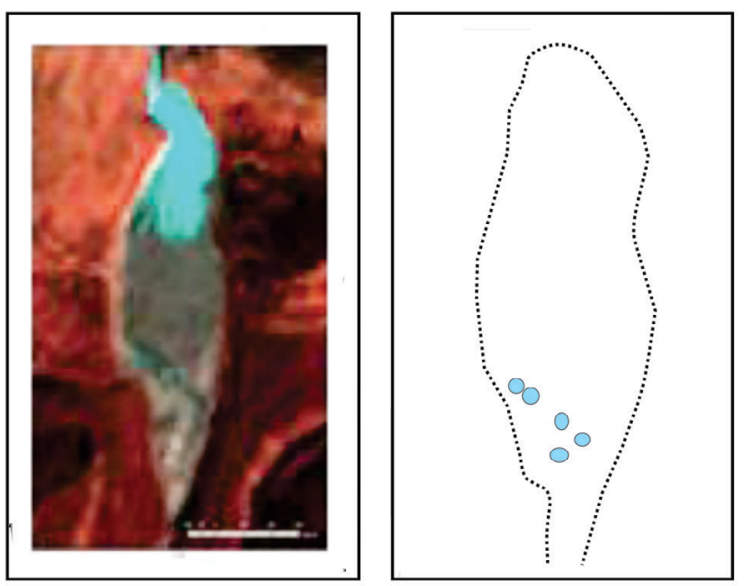

2000 January: Formation of Lake area 10455.52 sq. $\mathrm{m}$.
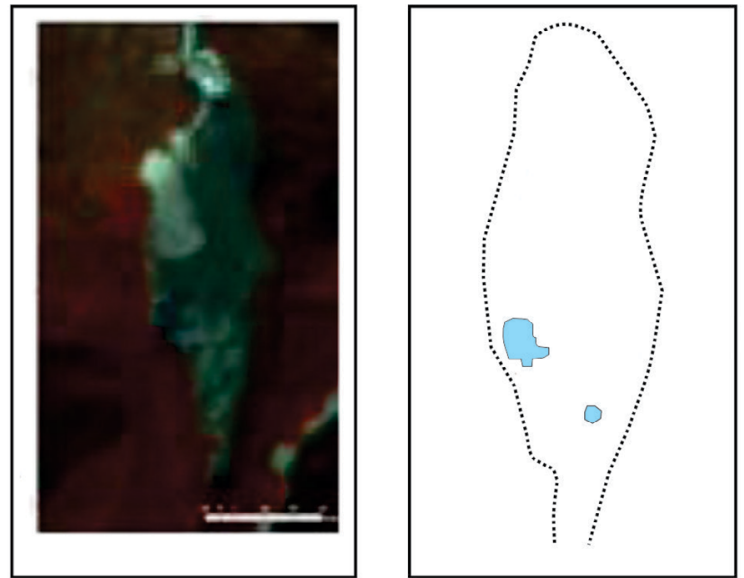

2005 January: Landsat image, Lake expansion 16784.84 sq. m.
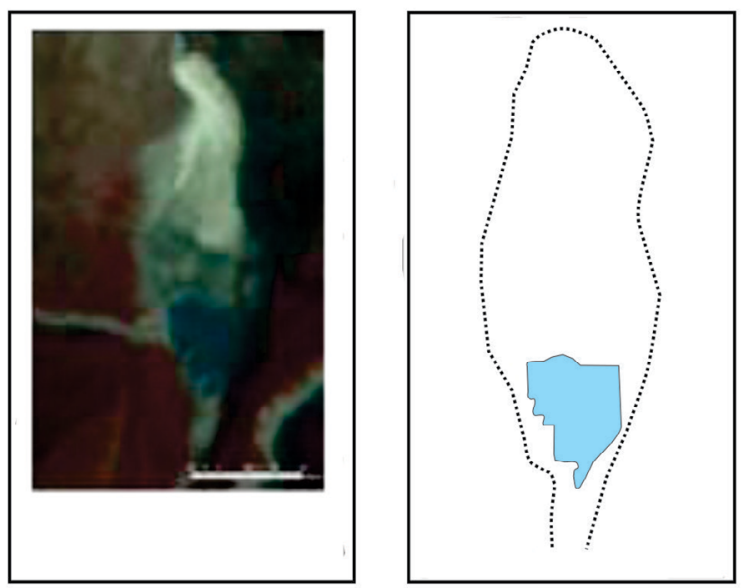

2010 March: Lake drastically change and reached $95502.45 \mathrm{sq} . \mathrm{m}$.
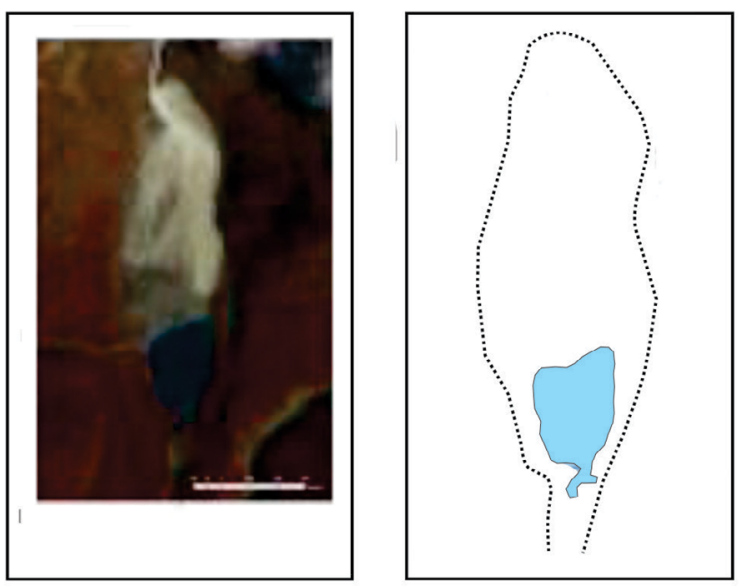

2016 March: Landsat image, Lake expansion and reached $104040 \mathrm{sq} . \mathrm{m}$.

Fig. 3: Change in Lake area over 1990 to 2016. 
Table 1: Change in area of lake from 1990-2016

\begin{tabular}{|l|l|l|}
\hline S.N. & Date of Landsat images & Area of lake $\left.\mathbf{( m}^{\mathbf{2}}\right)$ \\
\hline 1 & 1990 & n/a \\
\hline 2 & 2000 & $10,455.52$ \\
\hline 3 & 2005 & $16,784.84$ \\
\hline 4 & 2010 & $98,602.45$ \\
\hline 5 & 2016 & $104,040.69$ \\
\hline
\end{tabular}

\section{CONCLUSIONS}

The Kahphuche glacial lake, located at the source of the Madi River, has increased perceptibly in size over the last one and half decades, and it continues to expand. The area of the lake is 10.40 hectares and has increased to almost 10 folds over the period of 15 years. A detailed study of the lake is important to assess the hazard the lake will bring up to avoid the possible danger in the downstream. This article elucidates the temporal change of the glacial lake condition only which is a part of larger study project entitled Assessment of Kahphuche (Gopche) glacial lake expansion and its potential impact in Kaski, Tanahun and Lamjung Districts, Nepal: Using geospatial tools.

\section{ACKNOWLEDGEMENT}

This study was conducted in the financial support of USAID funded Hariyo Ban Program through WWF Nepal. We would like to thank Department of Geography, Prithvi Narayan Campus, Pokhara and Institute of Engineering, Paschimanchal Campus, Pokhara for technical support.

\section{REFERENCES}

Dahal, R. K., and Hasegawa, S., 2008, Representative rainfall thresholds for landslides in the Nepal Himalaya, Science Direction, Geomorphology, v. 100, pp. 429-443.

Bajracharya, S. R., Mool, P. K., and Joshi, S. P., 2002, Spatial database development of glaciers glacial lakes in the identification potentially dangerous glacial lakes of Nepal using remote sensing and geographic information systems. In Asian Conference on Remote Sensing.

ICIMOD, 2010, Glacial Lakes and Associated Floods in the Hindu Kush Himalayas, Information Sheet \#2/10, Kathmandu, Nepal.

Shrestha, N. and Balla, M. K., 2011, Temporal change detection of Lumding Tsho glacial lake in Dudh-Koshi Basin, Nepal. Journal of Environmental Research and Development. v. 5(3A), January-March, 2011.

Shroder, J. F. and Bishop, M. P., 1998, Mass movement in the Himalaya: new insights and research directions. Geomorphology, v. 26, pp. 13-35. 